\title{
ROBERT STEFANICKI
}

https://doi.org/10.33995/wu2021.2.1

\section{Kilka uwag w sprawie weryfikacji administracyjnej kandydatów na członków zarządu zakładu ubezpieczeń i reasekuracji}

Sama idea sprawowania częściowego nadzoru personalnego przez Komisję Nadzoru Finansowego nad rynkiem finansowym nie jest kwestionowana, jako że może się ona wpisywać w całokształt mechanizmów składajacych się na ład korporacyjny. Jednakże niektóre sposoby jej urzeczywistnienia nasuwaja watpliwości. Zastrzeżenia dotyczq oceny kryteriów weryfikacji przyjmowanych przez wskazany organ, wychodzenia poza granice kompetencji przy wydawaniu niektórych aktów. Ingerencja regulatora w działalność ubezpieczeniowq musi być wyważona i dqażyć do pogodzenia celu nadzoru z celem funkcjonowania zakładu ubezpieczeń jako spółki akcyjnej. Realizacja administracyjnego nadzoru personalnego dotyczy również interesu prawnego ocenianego w tym trybie.

Słowa kluczowe: klauzula generalna, zgoda organu nadzoru, interes prawny, luz decyzyjny, rękojmia należytego wykonywania obowiązków.

\section{Wprowadzenie}

Prawidłowe funkcjonowanie rynku finansowego, w tym banków oraz zakładów ubezpieczeń i reasekuracji, jego stabilność oraz budowanie zaufania klientów jest niezwykle istotne. Niekwestionowana jest również rola nadzoru nad nim pełnionego przez KNF, mającego na celu jego zabezpieczenie w granicach przyznanych temu organowi ustawowych kompetencji. Ważne jest też, aby w praktyce ich wykonywania ingerencja władcza Komisji w funkcjonowanie podmiotów prawa prywatnego objętych personalnym nadzorem była ściśle ukierunkowana na zakładane jej cele. Dotyczy to m.in. wydawanych przez nią decyzji w sprawie zgody na powołanie dwóch członków zarządu. Na kwestiach tych zostanie skupiona główna uwaga w poniższych rozważaniach. 


\section{Procedura weryfikacji odpowiedniości kandydata na członka zarządu zgodna z jej celem}

Zgodnie z art. 2 ustawy z dnia 21 lipca 2006 roku o nadzorze nad rynkiem finansowym ${ }^{1}$ celem nadzoru jest zapewnienie prawidłowego funkcjonowania tego rynku, zabezpieczenie jego stabilności, bezpieczeństwa, przejrzystości oraz zaufania społecznego, a także zapewnienie ochrony interesów jego uczestników². Do realizacji celów nadzoru konieczne było wyposażenie organu nadzoru we władcze kompetencje. W tych granicach organ administracyjny ma realizować skutecznie założone cele. W doktrynie zgłaszane są wạtpliwości, czy niektóre ze stosowanych środków nie wychodza poza zakres przyznanych organowi ustawowych uprawnień. Dotyczy to m.in. pisma przyjętego przez Komisję w dniu 27 stycznia 2020 roku, adresowanego do rad nadzorczych oraz zarządów banków, jednostek zarządzających systemami ochrony instytucjonalnej, zakładów ubezpieczeń i reasekuracji, towarzystw emerytalnych oraz domów maklerskich, zatytułowanego Metodyka oceny odpowiedniości członków organów podmiotów nadzorowanych.

W uzasadnieniu dokumentu podniesiono, że „Prawidłowe przeprowadzanie procesu oceny odpowiedniości członków organów zarządzających oraz nadzorujących w podmiotach rynku finansowego jest kluczowym elementem zdrowego ładu korporacyjnego i realnego ukształtowania poziomu kompetencji i odpowiedzialności. Osoby mające wpływ na sposób prowadzenia regulowanej działalności finansowej muszą być zdolne do codziennego podejmowania należytych, ostrożnych decyzji zapewniających stabilność i bezpieczny rozwój zarządzanych przez nie podmiotów". Z tego względu muszą one spełniać kryteria odpowiedniości i podlegać regularnemu procesowi oceny. Założeniem Komisji było osiagnięcie - w oparciu o stosowanie wymogów niniejszego zbioru - dostatecznej transparentności i przewidywalności procedury weryfikacji. Decyzje miały być podejmowane na podstawie „jednakowych, znanych i zrozumiałych” zasad. Dokonując ścisłej ich interpretacji pod kątem adresata Metodyki, można byłoby wyciagną́c wniosek, że nie dotyczy ona nadawcy. Sens jednak tego rodzaju aktywności Komisji dostrzec należy w spójnym traktowaniu wymogów przez organ nadzoru zakładu ubezpieczeń oraz przez Komisję.

\section{Zastrzeżenia odnośnie do oceny kryteriów przyjętych przez Komisję w Metodyce}

Wskazany dokument stanowić miał odpowiedź na potrzeby rynku, zwłaszcza trudności występujące przy stosowaniu kryteriów odpowiedniości członków organów podmiotów nadzorowanych. Pismo spotkało się zasadniczo z krytycznymi ocenami doktryny. Nie kwestionuje się w nich uprawnień KNF w zakresie wykonywania przez ten organ nadzoru instytucjonalnego i zintegrowanego nad rynkiem finansowym. Zgłoszone wạtpliwości dotyczą oceny przyjętych przez nią kryteriów z punktu widzenia ich zgodności z zasadą legalizmu i praworządności, a zasady te wywodzone

1. Tekst jedn. Dz. U. 2015, poz. 614 z późn. zm.

2. Z kolei zgodnie z art. 3 ustawy z dnia 22 maja 2003 r. o nadzorze ubezpieczeniowym i emerytalnym jego celem jest ochrona interesu osób ubezpieczających, ubezpieczonych, uposażonych lub uprawnionych z umów ubezpieczenia. 
są wprost z idei demokratycznego państwa prawnego z art. 2 oraz z art. $?$ Konstytucji ${ }^{3}$. Ten ostatni stanowi, że organy władzy publicznej działają na podstawie i w granicach prawa. Mając na uwadze wymogi konstytucyjne ${ }^{4}$ stawiane ustawo dawstwu zwykłemu i jego wykonywaniu, nie sposób byłoby pominąć w związku z powyższym stanowiskiem krytycznych ocen wymogów odnoszạcych się do weryfikacji kandydatów na członków zarządu zakładu ubezpieczeń i reasekuracji.

\section{Legalność a otwartość prawa}

W prawie administracyjnym mamy do czynienia zarówno z kryterium podstawowym, jakie stanowi legalność, jak i z instrumentami służącymi elastyczności prawa. Legalność odnoszona jest zarówno do stanowienia prawa, jak i do jego wykładni oraz stosowania w trybie postępowania administracyjnego, a także w toku sądowej kontroli działań administracji. Jako aksjologiczny punkt odniesienia w kulturze prawa stanowionego zasada legalności jest łączona ze zgodnościa prowadzonego postępowania i treści decyzji z przepisami prawa, stanowiącymi odrębny element regulacji normatywnej, usytuowanej w zasadniczej części najważniejszych dla danej dziedziny aktów. W prawie administracyjnym zawierane są również instrumenty służące dostosowywaniu prawa do zmienności jego otoczenia i oczekiwań społecznych. W otwartym modelu prawa - w odróżnieniu od modelu autonomicznego, zamkniętego - mamy dwa wektory zasad jego konstruowania i stosowania, tj. ze wspomniana już legalnością w rozumieniu formalno-prawnym oraz środkami służącymi elastyczności. Do tych drugich zalicza się w szczególności zewnętrzne odesłania generalne. W literaturze przedmiotu podniesiono, że relacje między nimi można postrzegać w kategoriach wartości przeciwstawnych ${ }^{5}$. Takie zestawienie wydaje się uprawnione jedynie w odniesieniu do sposobu realizacji celu danej regulacji, źródeł wartości prawnych czy pozaprawnych i konsekwencji tego stanu. Legalność dotyczy oparcia procesu decyzyjnego i samej decyzji na kryteriach normatywnych sensu stricte. Osiagana jest ona w oparciu o mechanizmy wewnątrzprawne.

Elastyczność jest efektem stosowania mechanizmów otwierających prawo na czynniki zewnętrzne, zwłaszcza na oceny dominujące w społeczeństwie lub wyodrębnionej jego grupie. Najczęściej odbywa się to z wykorzystaniem reguł słuszności i sprawiedliwości w obydwu jej wymiarach. Ze stosowaniem tych instrumentów łączy się osłabienie stabilności i pewności prawa ${ }^{6}$.

3. Taki pogląd prezentują m.in. M. Romanowski, K. Zarzycka, Ocena kryteriów przyjętych przez Komisję Nadzoru Finansowego $w$ „Metodyce oceny odpowiedniości członków organów podmiotów nadzorowanych z 2020 roku”, „Wiadomości Ubezpieczeniowe” 2020, nr 3, s. 5 i nast. W kwestii szerokiego formalnego i materialnego ujmowania praworządności zob. J. Nowacki, Rzqdy prawa. Dwa problemy, Wydawnictwo UŚ, Katowice 1995, s. 33.

4. Ten kontekst stosowania prawa w szerszym przedmiotowym zakresie podejmuje K. Szczucki, W poszukiwaniu dóbr chronionych w Konstytucji, „Forum Prawnicze” 2011, nr 4-5, s. 55 i nast.

5. L. Leszczyński, [w:] Wykładnia w prawie administracyjnym. System prawa administracyjnego. Tom 4, [red.] R. Hauser, A. Wróbel, Z. Niewiadomski, CH Beck, Warszawa 2015, rozdział 1, §3, pkt II, s. 31.

6. Szerzej P. Kaczmarek, Materialne i proceduralne aspekty prawa. Wstęp do rozważań nad przejawami proceduralizacji w prawie europejskim, [w:] Z zagadnień teorii i filozofii prawa. Teoria prawa europejskiego, [red.] J. Kaczor, „Acta Universitatis Wratislaviensis” nr 2760, Wrocław 2005, s. 136. 
Wymienione wartości prawa mogą być traktowane jako wzajemnie się uzupełniające i przenikające ${ }^{?}$, zważywszy że uelastycznienie opierane jest na odesłaniu zawartym w samych przepisach i z tej perspektywy traktowane jako praworządne ${ }^{8}$. Chodzi tutaj więc o wykorzystywanie w praktyce odesłań generalnych, celowo wprowadzonych do tekstu prawnego, ukierunkowanych na pozaprawne ocenianie i ostateczną sytuacyjną weryfikację ich przez organ administracji lub sąd. Konstrukcje takie opierają się na założeniu istnienia naturalnego luzu decyzyjnego w procesie ich zastosowań. Ustawodawca wprowadza je do tekstu prawnego celowo, ale nie może przewidzieć sposobu z nich korzystania w praktyce przez uprawniony organ ${ }^{9}$. Z obydwoma wymienionymi tutaj wartościami prawa mamy do czynienia w procesie decyzyjnym weryfikacji administracyjnej kandydatów na członków zarządu zakładu ubezpieczeń i reasekuracji. Zatem zawarcie w tekście prawnym zwrotu niedookreślonego o charakterze generalnego pozaprawnego odesłania stanowi tutaj wyraz celowego działania ustawodawcy, który w ten sposób dąży do zachowania niezbędnej elastyczności ze względu na naturę zjawiska poddanego regulacji. Chodzi o zagwarantowanie możności zastosowania omawianej konstrukcji do wielu zróżnicowanych stanów faktycznych, których nie da się lub nie należy ujmować w normatywne katalogi ${ }^{10}$. Klauzula generalna nie stanowi odesłania do gotowej normy czy sformatowanych normatywnie elementów. Wymaga „szycia na miarę" konkretnego przypadku zależnie od złożoności danego podmiotu i potrzeb ${ }^{11}$. Dotyczy to także rękojmi należytego sprawowania mandatu przez zarządcę.

\section{Cel nadzoru personalnego sprawowanego przez KNF}

Jednym z uprawnień nadzorczych KNF jest wyrażenie przez nią zgody na powołanie dwóch członków zarządu krajowego zakładu ubezpieczeń lub krajowego zakładu reasekuracji: prezesa oraz członka zarządu odpowiedzialnego za obszar zarządzania ryzykiem ${ }^{12}$. Zgodnie z brzmieniem art. 3 ustawy o nadzorze ubezpieczeniowym i emerytalnym celem nadzoru jest ochrona interesów ubezpieczających, ubezpieczonych, uposażonych lub uprawnionych z umów ubezpieczenia, członków funduszy emerytalnych, uczestników pracowniczych programów emerytalnych, osób utrzymujacych emeryturę kapitałową lub osób przez nie uposażonych. Wymogi stawiane kandydatom określa art. 48 ust. 1 ustawy o działalności ubezpieczeniowej. Stanowi on, że członkiem zarzadu może być osoba, która spełnia łącznie następujące wymagania: ma pełną zdolność do czynności

7. Trafnie zauważa M. Florczak-Wator ([w:] Kontrola konstytucyjności klauzul generalnych, „Przegląd Sejmowy” 2013, nr 4, s. 50), że stosowanie klauzul służy humanizacji prawa. Za ich pośrednictwem normy i wartości pozaprawne przenikają do prawa stanowionego i wywieraja wpływ na sposób jego rozumienia i stosowania. Zob. też interpretację Trybunału Konstytucyjnego zmierzająca w podobnym kierunku z dnia 7 grudnia 1999 r., K 6/99.

8. L. Leszczyński, op. cit., s. 31.

9. Oprócz generalnych klauzul odsyłających źródłem specjalnie wykreowanych w ustawach luzów są wartości aksjologii wewnątrzprawnej „wydobywane” ze zwrotów szacunkowych, wyrażeń celowo niedookreślonych lub normatywnych podstaw decyzji uznaniowych, co ma istotne znaczenie w szczególności dla administracyjnego trybu stosowania prawa.

10. M. Romanowski, K. Zarzycka, op. cit., s. 12

11. D. Wajda, Kwalifikacje członków zarzqdu na gruncie kodeksu spółek handlowych w prawie bankowym oraz ubezpieczeniowym i reasekuracyjnym, „Przegląd Prawa Handlowego” 2010, nr 4, s. 1 ?.

12. Art. 51 ust. 1 ustawy o działalności ubezpieczeniowej i reasekuracyjnej. 
prawnych; posiada wyższe wykształcenie uzyskane w Rzeczpospolitej Polskiej lub uzyskane w innym państwie wykształcenie będące wykształceniem wyższym w rozumieniu właściwych przepisów tego państwa; nie była skazana za umyślne przestępstwo lub umyślne przestępstwo skarbowe prawomocnym wyrokiem sądu i daje rękojmię prowadzenia spraw zakładu w sposób należyty. Zauważyć należy, że wskazane przesłanki nie mają jednolitego charakteru. Niektóre z wymienionych elementów są dokładnie oznaczone w cytowanym przepisie. Warunek odnoszący się do dawania rękojmi prowadzenia spraw zakładu w sposób należyty stanowi rodzaj generalnego odesłania pozaprawnego. Brane pod uwagę kryteria odpowiedniości kandydata są dookreślane dopiero na etapie zastosowań omawianej procedury.

\section{Dawanie rękojmi sprawowania przyszłego zarządu w sposób należyty}

Rękojmia jest zaliczana do kategorii odesłania generalnego i ogólnego wyrażonego w przepisie zwrotem niedookreślonym ${ }^{13}$. Zgodność tej metody regulacji, zwłaszcza z punktu widzenia wymogu stanowienia przyzwoitej legislacji wyprowadzanego z art. 2 Konstytucji, była wielokrotnie badana przez Trybunał Konstytucyjny, przy czym jego stanowiska trudno byłoby sprowadzić do wspólnego mianownika ${ }^{14}$. Podniesiono już, że konsekwencją stosowania odesłań generalnych jest osłabienie pewności prawa ${ }^{15}$, przewidywalności rozstrzygnięć w podobnych sprawach dla jego adresatów. Jest to cena, jaką płaci się za rozstrzyganie zgodne z wymogami słuszności i sprawiedliwości, a także potrzebą zabezpieczenia na tej drodze elastyczności prawa niezbędnej dla jego adaptacji do zmieniających się okoliczności i warunków bez korekty legislacyjnej. Klauzule służą też uproszczeniu prawa, przeciwdziałaniu zbytniej kazuistyce i jego inflacji. Kwestia braku dostatecznej określoności wymogu odnoszonego do dawania rękojmi ostrożnego i stabilnego zarządzania bankiem została podniesiona m.in. w skardze konstytucyjnej wniesionej przez SKOK ${ }^{16}$. Interpretując zgłoszone do TK wątpliwości, KNF, w przedstawionej argumentacji na rzecz zgodności z ustawą zasadniczą omawianej konstrukcji, stwierdziła, sięgając w tej materii do dotychczasowego dominującego stanowiska doktryny i orzecznictwa, że mamy tu do czynienia z klauzula generalną, wyrażoną zwrotem niedookreślonym - tutaj dotyczącym rękojmi - a więc kryterium ocennym, wyrażającym się odesłaniem do aksjologii pozaprawnej. Typowy dla tego rodzaju instytucji luz decyzyjny przy orzekaniu nie oznacza, zdaniem KNF, że organowi administracji publicznej zostało przyznane niczym nieograniczone prawo do interpretowania i doboru wyznaczników ich treści.

13. M. Safjan, Klauzule generalne w prawie cywilnym (przyczynek do dyskusji), „Państwo i Prawo” 1990, nr 11, s. 51.

14. Zważywszy, że w niektórych jego wyrokach, w tym w uzasadnieniu wyroku z dnia 17 października $2000 \mathrm{r}$. (SK 5/99), Trybunał przyjałł restrykcyjną interpretację wyznaczników klauzuli generalnej, uzasadniając swoje stanowisko wymogami pewności prawa. W krytycznej ocenie tego orzeczenia podniesiono, że trudno byłoby zaakceptować ścisłą obiektywizację ocen i jednolitą interpretację treści klauzul, bo pozostawałoby to w opozycji do naturalnych właściwości i celów pozaprawnych odniesień.

15. J. Parchomiuk, Nadużycie prawa w prawie administracyjnym, CH Beck, Warszawa 2018, s. 652.

16. Zob. postanowienie TK z 27 października 2015 r., SK 2/14, OTK ZU-A2015, nr 9, poz. 158. 


\section{Naturalna niedookreśloność wyznaczników klauzuli generalnej}

Praworządny - w związku z umieszczeniem odesłania w akcie rangi ustawowej - charakter klauzuli generalnej oznacza, że organ rozstrzygający na tej podstawie ma nie tylko prawo, ale i obowiązek, z zastrzeżeniem poszanowania przezeń reguł wykładni, dokonania subsumcji oraz przeprowadzenia postępowania dowodowego w zakresie pozwalającym na wypełnienie stosownymi wyznacznikami jej treści ${ }^{17}$. Zgodnie z koncepcją sytuacjonistyczną treść klauzul dookreśla się na potrzeby konkretnego rozstrzygnięcia, uwzględniając cel danej regulacji oraz aktualne konteksty ${ }^{18}$. Trybunał w uzasadnieniu niniejszego wyroku podniósł, że dla wykazania trafności zarzutu naruszenia wymogów poprawnej legislacji przy stanowieniu tego rodzaju generalnych odesłań należałoby dostarczyć stosownych dowodów na tak daleko idącą rozbieżność lub niejasność praktyki, która dyskwalifikowałaby ten mechanizm jako unormowanie regulujace administracyjną reglamentację w państwie prawa. Z analizy zaskarżonego skargą konstytucyjną przepisu, a zwłaszcza z jego wdrażania, nie wynika zdaniem Trybunału, aby brak precyzji, naturalnej dla niedookreślonych zwrotów takich jak dawanie rękojmi sprawowania zarządu w sposób należyty, byłźródłem istotnych problemów związanych z jego odczytywaniem, czyli miał negatywny wpływ na dookreślenie w praktyce stosowania prawa jednego z ważnych kryteriów oceny wniosku o zgodę organu na zarządzanie instytucją finansową ${ }^{19}$.

\section{Aprobata dla edukacyjnej aktywności Komisji}

KNF wykazuje dużą aktywność w wydawaniu opinii, wytycznych i materiałów edukacyjnych, adresowanych do podmiotów przez nią nadzorowanych ${ }^{20}$. Niektóre z nich budzą wạtpliwości doktryny co do zgodności z prawem. Przykładem tego rodzaju wytycznych Komisji, ukierunkowanych na rozwiązywanie kwestii korporacyjnych w zakładach ubezpieczeń, jest - oprócz wspomnianej

17. Niewystarczające jest zatem powołanie się na określoną klauzulę, ale niezbędne jest dookreślenie wyznaczników jej treści w procesie stosowania prawa, szerzej D. Leśniak, [w:] Ustawa o działalności ubezpieczeniowej i reasekuracyjnej. Komentarz, [red.] M. Szczepańska, P. Wajda, Wolters Kluwer, Warszawa 2017, pkt 7 i nast. uwag do art. 48, A. Żurawik, Interes publiczny w prawie gospodarczym, CH Beck, Warszawa 2013, s. 463.

18. Por. wyrok TK z dnia 17 października 2000 r. Zob. uwagi M. Moczulskiej, Klauzula ważnego interesu podatnika oraz interesu publicznego a swoboda decyzyjna organu, [w:] Klauzule generalne w prawie krajowym i obcym, [red.] L. Zacharko, Wydawnictwo UŚ, Katowice 2016, s. 167. Należy w tym miejscu dodać, że najbardziej istotną zmianę $w$ sferze relacji między przedsiębiorcą a urzędami miała wprowadzić ustawa z dnia 6 marca 2018 r. - Prawo przedsiębiorców, Dz. U. 2018, poz. 646 z późn. zm. Kreuje ona domniemanie uczciwości przedsiębiorcy. To nowe podejście powinno także rzutować na omawiane procedury postępowań przed KNF.

19. Zresztą w skardze kasacyjnej wniesionej przez instytucję finansową nie wskazano - co byłoby tutaj istotne - na konkretne rozstrzygnięcia organu administracji ani na wyroki sądów administracyjnych, z których wynikałoby, że w procesie wdrażania prawa przesłanka dawania rękojmi zarządzania bankiem była różnie interpretowana, ze skutkami nieuzasadnionego zróżnicowania sytuacji prawnej adresatów prawa.

20. Rekomendacje KNF stwarzają możliwość punktowania rozsądnych oczekiwań w zakresie przestrzegania dobrych praktyk ubezpieczycieli i metod wychodzenia im naprzeciw, zob. M. Orlicki, Projektowanie typu ubezpieczenia („produktu ubezpieczeniowego”) według rekomendacji KNF dla zakładów ubezpieczeń dotyczqcych systemu zarzqdzania produktem, „Prawo Asekuracyjne” 2016, nr 3, s. 3-4. 
już na wstępie rozważań Metodyki - wydany w 2014 roku dokument zatytułowany Zasady ładu korporacyjnego dla instytucji nadzorowanych. Dotyczy on rekomendowanego przez ten organ sposobu ułożenia wewnątrzkorporacyjnych relacji w podmiotach przez nią nadzorowanych. Daleko idąca ingerencja w stosunki wewnątrzspółkowe w części dotyczącej corporate governance została krytycznie oceniona w nauce z uzasadnieniem, że wymieniony organ w wielu proponowanych zasadach narusza fundamenty prawa spółek ${ }^{21}$ lub konkretne reguły korporacyjne ${ }^{22}$.

Na aprobatę zasługują natomiast wydawane przez KNF materiały edukacyjne i wyjaśniające istotę nadzoru i jego funkcje ${ }^{23}$. Do tej kategorii zalicza się wskazywanie przez KNF wyznaczników istotnych dla oceny rękojmi kandydatów na członków organów podmiotów nadzorowanych. W jednym z dokumentów ${ }^{24}$ Komisja podniosła, że ustawodawca, posługując się otwartą konstrukcją regulacji, w związku z zawarciem w przepisie odesłania generalnego o charakterze zewnętrznym ${ }^{25}$, wychodziłz założenia, że praktyka biznesowa jest na tyle bogata, iż nie sposób dokonać wyliczenia wszystkich szczegółowych elementów, których spełnienie dawałoby rzeczywista prognozę na przyszłość, że oceniany w tym trybie kandydat daje rękojmię należytego wykonywania funkcji członka organu. KNF trafnie umiejscowiła omawianą klauzulę w kontekście pozostałych warunków normatywnych, które spełnić ma weryfikowany kandydat. Dlatego też w praktyce stosowania przedmiotowych regulacji przyjmuje się, że na przesłankę rękojmi składa się wiele elementów, które są oceniane przez organ łącznie. Pozwala to zweryfikować całościowo profil kandydata na członka organu, w szerokim kontekście jego dotychczasowej działalności zawodowej. Mamy tutaj do czynienia ze stawianiem prognozy przyszłej przydatności zarządcy.

21. Na temat ochrony interesu spółki więcej R. Stefanicki, Należyta staranność zawodowa członka zarzqdu spółki kapitałowej, Wolters Kluwer, Warszawa 2020, s. 81 i nast.

22. Zob. M. Romanowski, P. Haiduk, Oddziaływanie Komisji Nadzoru Finansowego na kwestie korporacyjne w zakładach ubezpieczeń w świetle Zasad Ładu Korporacyjnego dla instytucji nadzorowanych, „Wiadomości Ubezpieczeniowe" 2016, nr 3, s. 143 i nast.; M. Romanowski, A.M. Weber-Elżanowska, Kika refleksji na temat kompetencji Komisji Nadzoru Finansowego do wydania Zasad Ładu Korporacyjnego do instytucji nadzorowanych, [w:] „Wiadomości Ubezpieczeniowe” 2016, nr 3, s. 132 i nast. Również wątpliwości w kwestii zgodności z prawem Zasad ładu korporacyjnego podnosi A. Adamska, Projekt zasad ładu korporacyjnego dla instytucji nadzorowanych - ocena w świetle zasady proporcjonalności, Warszawa 2014, s. 11 i nast., s. 19. Zdaniem Autorki ich stosowanie ma być weryfikowane przez wydający je organ, a zatem uznać należy je za zbyt rygorystyczne, a w niektórych kwestiach, w tym w zakresie obowiązku dokapitalizowania spółki - sprzeczne z prawem.

23. Szerzej M. Romanowski, A.M. Weber-Elżanowska, op. cit., s. 144.

24. Zob. pismo z 4 sierpnia 2008 r., nr 254/2008 w sprawie Wytycznych i okoliczności istotnych dla oceny rękojmi kandydatów na członków organów podmiotów nadzorowanych.

25. Szerzej M. Korycka-Zirk, Filozoficznoprawny wymiar kontroli konstytucyjności prawa, TNOiK, Toruń 2017, s. 183 i nast. 


\section{Ingerencja administracyjna w obsadę kierowniczych stanowisk w instytucjach finansowych a zasada wolności gospodarczej}

Komisja ${ }^{26}$ kładzie też akcent na prognostyczny charakter procedowania przy weryfikacji sylwetki kandydata ${ }^{27}$. Stwierdza m.in., że w zakresie wypełniania przesłanki dawania rękojmi prowadzenia spraw zakładu ubezpieczeń/reasekuracji w sposób należyty uwzględniać należy dotychczasowe doświadczenia ocenianego i sposób wykonywania obowiązków w poprzednim zatrudnieniu. Moga one zarówno pozytywnie, jak i negatywnie rzutować na ocenę spełniania tego kryterium w przyszłości. Rękojmia jest tworzeniem prognozy odpowiedniości określonej osoby na sprawowanie zarządu, w oparciu o przeszłe jej działania, doświadczenia i osiągnięcia. Ingerencję KNF w działalność ubezpieczeniową, przyjmująca m.in. postać wyrażania zgody na obsadę kierowniczych stanowisk - w praktyce głównie chodzi o członków zarządu - należy zestawiać z fundamentalną w gospodarce rynkowej zasadą wolności gospodarczej, swobodą zakładania i prowadzenia działalności, nastawionej na osiągnięcie korzyści w sposób niesprzeczny z prawem i umowami społecznymi. Ograniczenie tej aktywności, jako wyjątek od zasady prowadzenia działalności gospodarczej, powinno być limitowane zasadniczymi celami nadzoru, gwarancjami bezpieczeństwa. Ingerencja Komisji w działalność zakładu ubezpieczeń, w tym w obsadę stanowisk kierowniczych, musi ograniczać się do podejmowania działań niewykraczających poza ramy kompetencji organu.

W interesie podmiotu nadzorowanego, a także w interesie kandydata objętego procedurą administracyjnej zgody na członka zarządu, leży transparentność zasad, jakimi kierować się ma organ w tej procedurze. Kwestią otwartą pozostaje, czy przyjęta przez KNF Metodyka oceny odpowiedniości członków organów podmiotów nadzorowanych spełniać będzie w praktyce użyteczne funkcje, czy wręcz przeciwnie - w związku z nagromadzeniem w niej wielości kryteriów oraz terminów ocennych, wbrew zapewnieniom nadawcy dokumentu, nie przysłuży się do transparentności stosowanych procedur ${ }^{28}$. Zasadniczo wyznaczniki odesłania zewnętrznego, z jakimi mamy do czynienia przy rękojmi, powinny być dookreślane dopiero na etapie wdrażania w praktyce, czyli w momencie dokonywania oceny przez organ. Niektóre zawarte w tym dokumencie mierniki weryfikacji kandydata wymagałyby doprecyzowania albo usunięcia ich ze zbioru. Przykładem może być jednoznaczne, pejoratywne dla ocenianego kwalifikowanie w Metodyce ogłoszenia upadłości podmiotu, w którym osoba objęta oceną pełni / pełniła funkcję w zarządzie / radzie nadzorczej, lub oddalenie wniosku o ogłoszenie upadłości ze względu na to, że majątek dłużnika nie wystarczał na pokrycie

26. Komunikat w sprawie roli i znaczenia realizacji przez zakłady ubezpieczeń i zakłady reasekuracji funkcji zgodności z przepisami, https://www.knf.gov.pl/o_nas/komunikaty?articleld=62617 \&p_id=18 [dostęp: 10.07.2021].

27. W tej materii na uwagę zasługują wytyczne Europejskiego Urzędu Nadzoru Bankowego i Europejskiego Urzędu Nadzoru Giełd i Papierów Wartościowych w sprawie oceny odpowiedniości członków organu zarządzającego i osób pełniących najważniejsze funkcje z 21 marca 2018 r. EBA/GL 2017/12, w których świetle przy weryfikacji przydatności kandydata na pełnienie funkcji zarządców w instytucjach finansowych powinna być brana pod uwagę dotychczasowa rzetelność zawodowa, wyrażająca się nie tylko wiedzą i doświadczeniem, ale też dotychczasowym zaangażowaniem w wykonywanie powierzonych funkcji.

28. M. Romanowski, K. Zarzycka (w: op. cit., s. 3 i nast.) stwierdzaja, że Metodyka nie dostarcza jednoznacznych i mierzalnych wytycznych profilu kandydata. W praktyce rady nadzorcze i akcjonariusze mogą utracić kontrolę nad doborem kandydatów optymalnych z punktu widzenia właścicielskiego. 
kosztu postępowania. W krytycznej ocenie tego kryterium personalnej weryfikacji podniesiono ${ }^{29}$, że upadłość sama w sobie nie jest zjawiskiem negatywnym, przesądzającym o braku umiejętności zarządzania. Nie musi być ona efektem błędów w kierowaniu instytucją, tylko efektem czynników zewnętrznych, na które oceniana osoba nie miała wpływu lub, racjonalnie przyjmujacc, nie mogła ich przewidzieć i stosownie do potrzeb na nie reagować.

\section{Wewnątrzkorporacyjna weryfikacja wstępna kandydata}

W kierowanym do rad nadzorczych banków stanowisku Urzędu Komisji Nadzoru Finansowego z dnia 29 października 2018 roku, dotyczącym przestrzegania wymogów w zakresie oceny odpowiedniości członków zarządu, trafnie został położony akcent na spoczywające na radach nadzorczych wymogi staranności w procesie przygotowywania wniosku kandydata w ramach weryfikacji wstępnej, wewnątrzkorporacyjnej. Stwierdzono w nim m.in., że przedstawienie Komisji sylwetki następnie ocenianego kandydata ma tworzyć obraz obiektywny, mieć charakter realny i konkretny, uwzględniający wszystkie argumenty za i przeciw, a nie jedynie formalny. KNF uznała za niedopuszczalne zaniechanie udostępnienia jej kompletnych i udokumentowanych danych, z których można byłoby wyprowadzić prognozę spełnienia przez kandydata warunków pełnienia funkcji prezesa lub członka zarządu odpowiedzialnego za ryzyko w instytucji finansowej. Dostarczone przez nadzór spółki materiały zawierać powinny przede wszystkim istotne argumenty przemawiajace za pozytywna weryfikacja przez organ nadzoru. Komisja przy tym zastrzega, że nie chodzi tu o sprostanie nadmiernym wymogom. Problem jednak w tym, że do identycznych aksjomatów wartościowania stosować się powinien organ wyrażający zgodę w postępowaniu administracyjnym, oceniający m.in. kandydata pod kątem spełnienia rękojmi oraz innych warunków, aby mogły one współgrać ze sobą.

\section{Działania weryfikacyjne Komisji w granicach uznania administracyjnego}

Stosowane przez Komisję środki nadzoru personalnego należy traktować jako uzupełnienie mechanizmu ze sfery prawa prywatnego kierowania właściwych ludzi na właściwe stanowiska ${ }^{30}$. Weryfikując wyznaczniki składające się na dawanie rękojmi należytego sprawowania mandatu przez kandydata, KNF działa w ramach uznania administracyjnego. Zasadniczo w przypadku zastosowań odesłania generalnego, o jakim tutaj mowa, kontroli sądowej nie podlega dobór zastosowanych kryteriów wartościowania, składających się na klauzulę. Dotyczy on jedynie dochowania przesłanek formalnoprawnych i materialnoprawnych. Nie oznacza to, że Komisja w decyzji odnoszącej się do wyrażenia (bądź nie) zgody na powołanie członka organu zakładu ubezpieczeń ma pełna swobodę i dowolność przy kreowaniu ocen, ponieważ jest związana procedurą administracyjną,

29. M. Romanowski, K. Zarzycka, op. cit., s. 14 .

30. P. Wajda, Zgoda Komisji Nadzoru Finansowego na powołanie dwóch członków zarzqdu krajowego zakładu ubezpieczeń lub krajowego zakładu reasekuracji - wybrane aspekty, „Wiadomości Ubezpieczeniowe” 2016, nr 1, s. 81,89 . 
która ma gwarancyjny charakter wobec prawa materialnego ${ }^{31}$. Jest ona zobligowana do uzasadnienia decyzji odmownej32, dotyczącej niewyrażenia zgodny na objęcie zarządu.

Decyzja jest wprawdzie kierowana do podmiotu nadzorowanego, ale oddziaływuje również na sytuację prawną negatywnie zweryfikowanego. Miał tego pełną świadomość Rzecznik Praw Obywatelskich ${ }^{33}$, który stwierdził, że oparcie kryteriów stawianych kandydatom na stanowiska podlegające nadzorowi Komisji na metodzie prognostycznej, która polega na badaniu faktów z przeszłości i wyciagganiu z nich wniosków co do przyszłego zachowania kandydata w roli osoby zarządzającej zakładem ubezpieczeń, powoduje, w przypadku negatywnej weryfikacji KNF, destabilizację ich kariery zawodowej, a nierzadko utratę zaufania bądź wykluczenie ze środowiska zawodowego ${ }^{34}$. Problem sytuacji prawnej odwołującego się podmiotu od decyzji omawianego organu nie został dotąd rozwiązany, a jest to zagadnienie rangi podstawowej, dotykające wykładni prawa i uwzględniania w tym procesie wartości, których ono jest nośnikiem. Ten newralgiczny punkt odniesienia, który nie może umknąć stosującemu prawo, przesądza o niedostatku formalno-dogmatycznego jego badania ${ }^{35}$, a dotyczy statusu osoby weryfikowanej w omawianym trybie ${ }^{36}$. Celem administracyjnego diagnozowania jest uwzględnienie w nim płaszczyzny aksjologicznej3?, aby w tych ramach uzyskać odpowiedź na pytanie, czy analizowane rozwiązanie normatywne prawidłowo i skutecznie realizuje zakładane cele społeczne ${ }^{38}$.

31. W teoretycznym ujęciu zob. L. Morawski, Zasady wykładni prawa, TNOiK, Toruń 2010, s. 275.

32. O wielostronnych funkcjach uzasadnień i skutkach zaniedbania tego wymogu w praktyce E. Łętowska, Prawo W „płynnej nowoczesności”, „Państwo i Prawo” 2014, nr 3, s. 11 i nast.

33. Pismo nr V.510.86.2016.GH.

34. Chodzi tu oczywiście o ochronę ocenianych w tej procedurze, której wynik nie był rezultatem rzetelnego badania w trybie wyrażania administracyjnej zgody. W tym samym duchu wypowiedział się NSA w uzasadnieniu postanowienia z dnia 6 listopada 2019 r., II GZ 137/19. Szerzej R. Stefanicki, Violation of the fair resolution principle in recruitment procedures for the positions of managers, "Polish Law Review" 2016, nr 1, s. 1.

35. J. Stelmach, Pozytywistyczne mity metody prawniczej, „Forum Prawnicze” 2012, z. 3, s. 12.0 mitach poznania prawniczego i skutkach konserwatyzmu prawniczego A. Sulikowski, K. Otręba, 0 potrzebie studiów krytycznych nad prawem konstytucyjnym, „Państwo i Prawo” 2017, nr 3 s. 9 i nast.

36. Zob. w tym zakresie teoretyczne rozważania zob. Z. Ziembiński, Metodologiczne zagadnienia prawoznawstwa, PWN, Warszawa 1974, s. 75, s. 89 i nast., L. Morawski, Główne problemy współczesnej filozofii prawa. Prawo w toku przemian, LexisNexis, Warszawa 2005, s. 36 i nast. Trafnie podnoszą P. Kardas, M. Gutowski ([w:] eidem, Wykładnia i stosowanie prawa w procesie opartym na Konstytucji, CH Beck, Warszawa 2017, rozdział V], że dyskursywny model wykładni i stosowania prawa służy gwarancjom spójności systemu normatywnego, szczególnie istotnemu w wypadku rozbieżności interpretacyjnych.

37. Trafnie zatem przyjmuje J. Zimmermann (Aksjomaty prawa administracyjnego, Wolters Kluwer, Warszawa 2013, s. ?7), że sensem i istotą aksjologiczną prawa administracyjnego jest spełnienie przezeń służebnej funkcji wobec jednostki i wspólnoty. W takim m.in. kontekście postrzega służebną funkcję postępowania administracyjnego, a zwłaszcza ewolucję, jaka się w nim dokonuje, F. Geburczyk (idem, Służebna funkcja postępowania administracyjnego jako paradygmat? Tło historyczne a perspektywa współczesna, „Państwo i Prawo" 2020, nr 7, s. 86 oraz powołane przez autora piśmiennictwo].

38. A. Szajkowski, 0 metodzie badania prawa handlowego, [w:] Kodeks spółek handlowych po 15 latach obowiqzywania, [red.] J. Frąckowiak, Wolters Kluwer, Warszawa 2018, s. 174 i nast. Trafnie przyjmują P. Jabłoński, P. Kaczmarek (op. cit., s. 61), że celem podważalności rezultatu interpretacji językowej jest zapobieganie złemu prawu w sensie technicznym oraz aksjologicznym. 


\section{Status prawny kandydata weryfikowanego przez KNF}

KNF i częściowo judykatura utrzymują stanowisko, że status strony postępowania administracyjnego przysługuje wyłącznie spółce, a nie - weryfikowanemu w tym trybie kandydatowi na członka zarządu. Przepisy odnoszące się do warunków uzyskania przedmiotowej zgody normuja sytuację prawną zakładów ubezpieczeń i reasekuracji, a nie osób mających być powołane na stanowiska, do których objęcia jest wymagana zgoda. Zdaniem organu w myśl przepisów ustalenia dotyczące spełniania przez weryfikowanego kandydata przesłanek określonych w przepisach ustawy o działalności ubezpieczeniowej i reasekuracyjnej, mimo że stanowia przedmiot działań w ramach postępowania administracyjnego, nie mają waloru rozstrzygnięcia o jego indywidualnych prawach i obowiązkach. Odmienną argumentacją posłużono się w niektórych wyrokach sądów administracyjnych. Naczelny Sąd Administracyjny w uzasadnieniu wyroku z dnia 20 września 2019 roku ${ }^{39}$ stwierdził, że ewentualny brak dostępu do procedury administracyjnej poprzez możliwość złożenia wniosku o ponowne rozpatrzenie sprawy wykluczyłby także sądową kontrolę prawidłowości rozstrzygnięcia organu, czy weryfikowany w administracyjnym trybie kandydat daje rękojmię prowadzenia spraw zakładu w sposób należyty w rozumieniu art. 48 ust. 1 pkt 4 ustawy o działalności ubezpieczeniowej i reasekuracyjnej. Decyzja w sprawie wyniku weryfikacji ma również wpływ na sytuację osoby, której dotyczył brak administracyjnej zgody na objęcie funkcji w spółce i - w konsekwencji - na prawo do wyboru i wykonywania przez ocenianego zawodu w rozumieniu art. 65 ust. 1 zdanie pierwsze Konstytucji RP40.

\section{Koncepcja prawa refleksowego}

Zdaniem NSA ustawodawca, określając norma prawną konkretne wymogi, jakie powinna spełniać dana osoba, aby mogła zostać członkiem zarządu zakładu ubezpieczeń, nadaje przy tym Komisji kompetencję do władczego rozstrzygania o powołaniu członka zarządu w oparciu o wskazane wymogi, reguluje również sytuację prawną tej osoby. Źródłem mechanizmów ochronnych moga być jednakowoż nie tylko regulacje, z których wynika wprost ochrona interesu prawnego jednostki, ale również takie rozwiązania normatywne, które określają sytuacje przez prawo chronione. Z taką sytuacją mamy tutaj do czynienia. Podniesiony tu sporny w orzecznictwie i w piśmiennictwie problem pokazuje dwie zasadnicze tendencje w stosownej wykładni, tj. zarówno formalno-dogmatyczne podejście ${ }^{41}$, prezentowane zwłaszcza przez organ nadzoru administracyjnego, jak

39. II GZK 1408/18. Podobnie NSA przyjął w uzasadnieniu postanowienia z dnia 6 listopada 2019 r., II GZ 137/19.

40. Praktyka pokazuje, że procedury weryfikacji nie zawsze są przez stosujące je organ dotrzymywane. Przykładem może być wyrok WSA z 13 lipca 2017 r. w Warszawie, sygn. VI SA 2368/16.

41. W wyroku z dnia 7 marca 2018 r. (sygn. II GSK 3460/17) NSA orzekł, że „postępowanie wpadkowe, które nie jest postępowaniem w sprawie, nie służy i nie może wręcz służyć czynieniu ustaleń w podstawowej dla bytu sprawy administracyjnej kwestii, jakąjest identyfikacja strony / stron danego postępowania. Ustalenie takie następuje w postępowaniu właściwym w oparciu o art. 28 k.p.a. oraz konkretny przepis prawa materialnego i dokonuje się na wstępie tego postępowania. Jeżeli zatem organ stwierdza brak przepisu sytuującego interes prawny określonego podmiotu prawa, to znaczy, że brak jest konstytutywnego elementu sprawy administracyjnej i prowadzić jej nie można", zob. też B. Adamiak, Uwagi o fenomenie otwartej regulacji instytucji 
i przebijające się jeszcze z trudnością responsywne ${ }^{42}$, otwarte podejście do stanowienia, interpretacji i stosowania w praktyce określonych instrumentów ${ }^{43}$. Duża rola przypada tutaj wyznaczeniu trendów przez naukę ${ }^{44}$, także w torowaniu koncepcji prawa refleksowego.

W otwartym modelu stanowienia i wykonywania prawa punkt ciężkości kładziony jest na cele regulacji, zwłaszcza aksjologiczny i prakseologiczny wymiar prawa. Jeżeli względy te przemawiają za wychodzeniem poza wykładnię językową przepisu, to organ stosujący powinien dokonać pogłębionej analizy w oparciu o kryteria celowościowo-funkcjonalne. W tym duchu wypowiedział się NSA w postanowieniu z dnia 6 listopada 2019 roku ${ }^{45}$, stwierdzając, że „władcze rozstrzygnięcie organu nadzoru nad rynkiem finansowym, polegające na stwierdzeniu, że osoba przedstawiona do zatwierdzenia nie daje rękojmi, o której mowa w art. 18 ust. 4 ustawy o s.k.o.k. ${ }^{46}$, wykracza poza sferę jedynie interesu faktycznego tej osoby. Powoduje nie tylko wygaśnięcie z mocy prawa przyznanego wcześniej mandatu związanego z pełnioną funkcją, ale jednocześnie wyłącza tę osobę z kręgu podmiotów, które moga skutecznie ubiegać się o powołanie na prezesa zarządu jakiejkolwiek spółdzielczej kasy oszczędnościowo-kredytowej (art. 21 ust. 2 pkt 4 ustawy o s.k.o.k.). Oceniając tę sytuację w szerszej perspektywie: prawomocne rozstrzygnięcie stwierdzające, że osoba przedstawiona do zatwierdzenia nie daje rękojmi ostrożnego i stabilnego zarządzania w rozumieniu art. 18 ust. 4 ustawy o s.k.o.k., może stać się także podstawą negatywnej oceny kandydata do pełnienia kluczowych funkcji w działalności towarzystw ubezpieczeniowych i reasekuracyjnych oraz banków - z uwagi na stosowane analogiczne warunki i kryteria ich oceny określone w art. 48 ust. 1 pkt 4 w zw. z art. 51 ust. 3 ustawy z dnia 11 września 2015 r. o działalności ubezpieczeniowej i reasekuracyjnej”.

procesowych, [w:] Fenomen prawa administracyjnego. Księga Jubileuszowa Profesora Jana Zimmermanna, [red.] W. Jakimowicz, M. Krawczyk, I. Niżnik-Dobosz Iwona, Wolters Kluwer, Warszawa 2019.

42. O wielorakich funkcjach tego pojęcia zob. P. Jabłoński, P. Kaczmarek, 0 grze interpretatora z tekstem prawnym i czynnikami pozatekstowymi w derywacyjnej koncepcji wykładni prawa, „Archiwum Filozofii Prawa i Filozofii Społecznej” 2020, nr 2, s. 60 i nast. Rozsądne otwieranie systemu normatywnego na aksjologię zewnętrzną i wewnątrzprawną zakłada responsywny model prawa, zyskujący coraz większe zainteresowanie i akceptację w środowisku prawniczym, a także - incydentalnie - w judykatach. Zob. na temat atutów tego modelu zob. A. Bator, P. Kaczmarek, Kim ma być wychowanek akademii prawniczej? 0 perspektywach budowania edukacji prawniczej wokół konstytucji, „Krytyka Prawa” 2018, nr 2, s. 21 i nast.

43. Za tą drugą koncepcja przemawia dodatkowo współczesne rozumienie prawodawcy i jego racjonalności. Trafnie przyjmuje A. Bator (idem, 0 adekwatności założeń derywacyjnej koncepcji wykładni do badań nad interpretacja prawa Unii Europejskiej, „Studia Prawa Publicznego” 2015, z. 2, s. 27) w kwestii roli współczesnego prawodawcy i założenia jego racjonalności. Jego zdaniem powyższe założenie nie powinno legitymować prawa jako prostego instrumentu „w rękach socjologicznego prawodawcy”, a rozumienie jego roli powinno sprzyjać aktywności interpretatora, dostosowującego rozumienie tekstu do potrzeb i oczekiwań społecznych. Powyższe podejście sprzyja rozumieniu funkcji judykatury w aspekcie twórczym.

44. Zagrożenie dla podstawowych wartości etycznych stanowią rosnące związki współczesnej nauki z przemysłem i polityką. Komercjalizacja i polityzacja niewątpliwie jej zagraża. Szerzej L. Morawski, Filozofia publiczna i zobowiqzania moralne, „Prawo i Więż” 2017, nr 2, s. 79.

45. Sygn. II GZ 137/19.

46. Ustawa z dnia 5 listopada 2009 r. o spółdzielczych kasach oszczędnościowo-kredytowych, dalej: ustawa o s.k.o.k. 


\section{Zakończenie}

Komentowane w tym materiale orzecznictwo ${ }^{47}$ broni koncepcji wykładni omawianych przepisów, w której świetle interes prawny kandydata skarżącego rozstrzygnięcie Komisji w sprawie wyrażania zgody na pełnienie funkcji członka zarządu w instytucji finansowej należy wywieść z prawa refleksowego. Kształtuje ono specyficzną więź prawną między podmiotem dysponującym publicznym prawem podmiotowym o charakterze pozytywnym a osobą trzecią dysponująca prawem publicznym negatywnym. Związek ten ma charakter powództwa materialnego i formalnego. Ten ostatni wiąże się z koniecznością ochrony procesowej podmiotu dysponującego prawem refleksowym w postępowaniu zmierzającym do wydania decyzji. Natomiast wymiar materialny wyraża się skutecznością posiadanych uprawnień. Stroną może być zatem nie tylko podmiot, który w razie merytorycznego zakończenia sprawy będzie adresatem decyzji rozstrzygającej wprost o jego prawach lub obowiązkach, ale także osoba, na której prawa i obowiązki wydana decyzja będzie oddziaływać pośrednio, wskutek jej powiązania z sytuacją prawną adresata decyzji. To otwarte, uzasadnione aksjologicznie podejście do wykładni prawa administracyjnego, u nas z trudnościami przebijające się w myśleniu prawniczym, przenosić powinno dyskurs prawniczy na grunt służebnej funkcji postępowania administracyjnego wobec jednostki.

Nieprzypadkowo tytuł opracowania został zawężony do kilku uwag. Materiał autorski dotyka ważkiej i złożonej problematyki funkcji personalnego nadzoru Komisji nad podmiotami rynku finansowego. Jej rozwinięcie zasługuje na szersze monograficzne opracowanie. Aby administracyjna weryfikacja mogła skutecznie realizować zakładane jej cele, przyjmowane przez organ kryteria odpowiedniości kandydata na członka wymienionego organu powinny być transparentne i co do meritum dostatecznie określane. Leży to w dobrze pojętym interesie nie tylko podmiotów nadzorowanych, ale również osób poddawanych weryfikacji. Nie można gubić z pola widzenia tego, że za litera prawa kryją się konkretne wartości. Za przypadkową weryfikacją stoją dramaty negatywnie ocenionych. Stąd na szerszą uwagę w dyskursie prawniczym, także w kontekście konstytucyjnym, zasługuje koncepcja prawa refleksowego.

\section{Wykaz źródeł}

Adamiak B., Uwagi o fenomenie otwartej regulacji instytucji procesowych, [w:] Fenomen prawa administracyjnego. Księga Jubileuszowa Profesora Jana Zimmermanna, Jakimowicz W., Krawczyk M., Niżnik-Dobosz I. [red.], Wolters Kluwer, Warszawa 2019.

Adamska A., Projekt zasad ładu korporacyjnego dla instytucji nadzorowanych - ocena w świetle zasady proporcjonalności, Warszawa 2014.

Bator A., 0 adekwatności założeń derywacyjnej koncepcji wykładni do badań nad interpretacja prawa Unii Europejskiej, „Studia Prawa Publicznego” 2015, z. 2.

Bator A., Kaczmarek P., Kim ma być wychowanek akademii prawniczej? 0 perspektywach budowania edukacji prawniczej wokół konstytucji, „Krytyka Prawa” 2018, nr 2.

47. W wyroku z dnia 20 września 2019, sygn. II GSK 1408/18 oraz w postanowieniu z dnia 6 listopada 2019 r., sygn. II GZ 137/19. 
Florczak-Wator M., [w: ] Kontrola konstytucyjności klauzul generalnych, „Przegląd Sejmowy” 2013, nr 4. Geburczyk F., Służebna funkcja postępowania administracyjnego jako paradygmat? Tło historyczne a perspektywa współczesna, „Państwo i Prawo” 2020, nr ?.

Jabłoński P., Kaczmarek P., 0 grze interpretatora z tekstem prawnym i czynnikami pozatekstowymi w derywacyjnej koncepcji wykładni prawa, „Archiwum Filozofii Prawa i Filozofii Społecznej” 2020, $\mathrm{nr} 2$.

Kaczmarek P., Materialne i proceduralne aspekty prawa. Wstęp do rozważań nad przejawami proceduralizacji w prawie europejskim, [w:] Z zagadnień teorii i filozofii prawa. Teoria prawa europejskiego, Kaczor J. [red.], „Acta Universitatis Wratislaviensis” nr 2760, Wrocław 2005.

Kardas P., Gutowski M., [w:] Kardas P., Gutowski M., Wykładnia i stosowanie prawa w procesie opartym na Konstytucji, CH Beck, Warszawa 2017.

Korycka-Zirk M., Filozoficznoprawny wymiar kontroli konstytucyjności prawa, TNOiK, Toruń 2017. Leszczyński L., [w:] Wykładnia w prawie administracyjnym. System prawa administracyjnego. Tom 4, Hauser R., Wróbel A., Niewiadomski Z. [red.], CH Beck, Warszawa 2015.

Leśniak D., [w:] Ustawa o działalności ubezpieczeniowej i reasekuracyjnej. Komentarz, Szczepańska M., Wajda P. [red.], Wolters Kluwer, Warszawa 2017.

Łętowska E., Prawo w „płynnej nowoczesności”, „Państwo i Prawo” 2014, nr 3.

Moczulska M., Klauzula ważnego interesu podatnika oraz interesu publicznego a swoboda decyzyjna organu, [w:] Klauzule generalne w prawie krajowym i obcym, Zacharko L. [red.], Wydawnictwo UŚ, Katowice 2016.

Morawski L., Filozofia publiczna i zobowiqzania moralne, „Prawo i Więź” 2017, nr 2.

Morawski L., Główne problemy współczesnej filozofii prawa. Prawo w toku przemian, LexisNexis, Warszawa 2005.

Morawski L., Zasady wykładni prawa, TNOiK, Toruń 2010.

Nowacki J., Rzqdy prawa. Dwa problemy, Wydawnictwo UŚ, Katowice 1995.

Orlicki M., Projektowanie typu ubezpieczenia [„produktu ubezpieczeniowego”] według rekomendacji KNF dla zakładów ubezpieczeń dotyczacych systemu zarzqdzania produktem, „Prawo Asekuracyjne" 2016, nr 3.

Parchomiuk J., Nadużycie prawa w prawie administracyjnym, CH Beck, Warszawa 2018.

Romanowski M., Haiduk P., Oddziaływanie Komisji Nadzoru Finansowego na kwestie korporacyjne w zakładach ubezpieczeń w świetle Zasad Ładu Korporacyjnego dla instytucji nadzorowanych, „Wiadomości Ubezpieczeniowe” 2016, nr 3.

Romanowski M., Weber-Elżanowska A.M., Kilka refleksji na temat kompetencji Komisji Nadzoru Finansowego do wydania Zasad Ładu Korporacyjnego do instytucji nadzorowanych, ,Wiadomości Ubezpieczeniowe" 2016, nr 3.

Romanowski M., Zarzycka K., Ocena kryteriów przyjętych przez Komisję Nadzoru Finansowego w „Metodyce oceny odpowiedniości członków organów podmiotów nadzorowanych z 2020 roku”, „Wiadomości Ubezpieczeniowe” 2020, nr 3.

Safjan M., Klauzule generalne w prawie cywilnym (przyczynek do dyskusji), „Państwo i Prawo” 1990, nr 11.

Stefanicki R., Należyta staranność zawodowa członka zarzqdu spółki kapitałowej, Wolters Kluwer, Warszawa 2020.

Stefanicki R., Violation of the fair resolution principle in recruitment procedures for the positions of managers, "Polish Law Review" 2016, nr 1. 
Stelmach J., Pozytywistyczne mity metody prawniczej, „Forum Prawnicze” 2012, z. 3.

Sulikowski A., Otręba K., O potrzebie studiów krytycznych nad prawem konstytucyjnym, „Państwo i Prawo" 2017, nr 3.

Szajkowski A., 0 metodzie badania prawa handlowego, [w:] Kodeks spółek handlowych po 15 latach obowiqzywania, Frąckowiak J. [red.], Wolters Kluwer, Warszawa 2018.

Szczucki K., W poszukiwaniu dóbr chronionych w Konstytucji, „Forum Prawnicze” 2011, nr 4-5. Wajda D., Kwalifikacje członków zarzqdu na gruncie kodeksu spółek handlowych w prawie bankowym oraz ubezpieczeniowym i reasekuracyjnym, „Przegląd Prawa Handlowego” 2010, nr 4.

Wajda P., Zgoda Komisji Nadzoru Finansowego na powołanie dwóch członków zarzqdu krajowego zakładu ubezpieczeń lub krajowego zakładu reasekuracji - wybrane aspekty, „Wiadomości Ubezpieczeniowe" 2016, nr 1.

Ziembiński Z., Metodologiczne zagadnienia prawoznawstwa, PWN, Warszawa 1974.

Zimmermann J., Aksjomaty prawa administracyjnego, Wolters Kluwer, Warszawa 2013.

Żurawik A., Interes publiczny w prawie gospodarczym, CH Beck, Warszawa 2013.

\section{A few remarks on the administrative review of specific candidate to be a member of the executive board of insurance and reinsurance undertaking}

The idea of partially personal supervising by the Polish Financial Supervision Authority over the financial market is not questioned, as it may be a part of the overall mechanisms of corporate governance. However, some necessary ways of its realization may raise doubts. The questions concern the assessment of verification criteria adopted by such Authority, which are beyond the limits of its competences to issue certain acts. Some regulator's intervention in insurance activities must be balanced and should aim at aligning the objectives of supervision with the purpose of the insurance company established as a joint-stock company under the Law on Insurance Business. The pursuit of these objectives should take account of the need to simplify administrative supervision and the legislative framework to as great an extent as possible and of the legitimate interest, assessed within the framework of this procedure.

Keywords: general clause, approval of the financial supervision authority, legitimate interest, the discretionary powers, guarantee to ensure discharge of all obligations.

PROF. DR HAB. ROBERT STEFANICKI - Wydział Prawa, Administracji i Ekonomii Uniwersytetu Wrocławskiego.

ORCID: 0000-0002-6087-4231

e-mail: robert.stefanicki@uwr.edu.pl 
